UDC: [616.72-002.77:796.012.412.3]:612.76

HTTPS://DOI.ORG/10.37647/0132-2486-2021-110-3-58-66

\title{
Biomechanical Analysis of the Joint and Muscle Forces of the Lower Extremities in Walking of Rheumatoid Arthritis Patient
}

\author{
Gerasymenko S.I. ${ }^{1}$, Lazarev I.A. ${ }^{1}$ 凶, Gerasymenko A.S. ${ }^{1}$, Babko A.M. ${ }^{1}$, \\ Poluliakh M.V. ${ }^{1}$, Litvynenko Yu.V. ${ }^{2}$, Zhyrnov O.V. ${ }^{2}$, Malovanyi S.D. ${ }^{3}$, Maksymishyn O.M. ${ }^{1}$
}

\begin{abstract}
Summary. Rheumatoid arthritis (RA) is an immunomodulated, chronic inflammatory disease, accompanied by the proliferation of the inflamed synovium and destruction of the articular cartilage, which leads to the formation of contracture of lower extremities joints and disability. Understanding the values of biomechanical loads on the articular surfaces with contracture of the joints of the lower extremities in patients with RA and the muscle forces (MF) participation in this process with the formation of adaptation and compensation mechanisms can contribute to the development of new views and approaches to the tactics of therapeutic measures specific to each stage of the disease. Objective: to analyze the bebavior of the musculoskeletal system of an RA patient in bis walking pattern by calculating the forces acting in the main muscle groups and joints of the lower extremities. Materials and Methods. Initial data were obtained from the examination of a female patient $K$., who was diagnosed with stage 2 phase 3 RA with a predominant lesion of the hip and knee joints and severe pain in the left hip joint. A video system of 6 cameras, reflective markers and a force platform were used for motion capture of the walking. A simulation musculoskeletal model of the gait of the RA patient using the AnyBody Modeling System 6.0 software (Denmark) was created. Joint reaction forces (JRF) and MF were calculated. Results. Normal mode of loading of the lower extremities was altered to compensate for structural disorders in joints of RA patients. The peaks of vertical component of the ground reaction force (GRF) are lower compared to the normal population; the gait is static and asymmetric, sparing. MF increase in m. gluteus (maximus, medius, minimus) with increasing amplitude of movements in the frontal plane. JRF of both hips increase in all planes. Conclusions. Walking of RA patients with limitation of active extensions in the hip and knee joints occurs due to an increase in the amplitude of the frontal plane compensatory movements. Postural muscle imbalance increases the $m$. gluteus, $m$. biceps femoris, $m$. semitendinosus and $m$. semimembranosus MF. Other lower extremities muscles decrease their MF. The MF redistribution is compensatory and aimed to keep the RA patient in the upright position and optimize the biomechanics of walking due to less painful movements. Biomechanical overloading of the hip and knee articular surfaces can serve as a factor in maintaining the inflammatory response, the development of degenerative processes, or the further progression of arthrosis and stiffness of the joints of the lower extremities in this category of patients.
\end{abstract}

Key words: rheumatoid arthritis; lower extremities contracture; AnyBody musculoskeletal model; joint reaction forces; muscle forces.

\section{Introduction}

Rheumatoid arthritis (RA) is an immunomodulated, chronic inflammatory disease accompanied by the proliferation of the inflamed synovium and destruction of the articular cartilage, leading to disability [1].

凶LazarevI.A., ilazarev@ukr.net

${ }^{1 S I}$ "Institute of Traumatology and Orthopedics of NAMS of Ukraine", Kyiv

${ }^{2}$ National University of Physical Education and Sport of Ukraine, Kyiv

${ }^{3}$ National Technical University of Ukraine "Igor Sikorsky Kyiv Polytechnic Institute", Kyiv
The etiopathogenesis of RA is still unclear; however, several stages of its pathophysiology have been elucidated, the key feature of which is inflammatory synovitis $[1,2]$. Although historically cartilage has been considered an "innocent bystander," recent evidence suggests that cartilage degradation in RA is associated with an imbalance in the anabolic and catabolic activity of articular chondrocytes associated with synovitis and joint inflammation indirectly. In addition to inflammation factors, the metabolic activity of chondrocytes is also influenced by mechanical stress factors [3]. 
In particular, biomechanical factors in rheumatoid arthritis can play an important role in the initiation and progression of degenerative processes in the joint, secondary to the inflammatory process $[4,5,6,7,8]$. However, the sequence of biomechanical and biochemical processes that regulate these events in vivo is not yet clear enough.

With the development of clinical gait analysis techniques (3D kinetics and kinematics), a necessary tool has emerged for finding differences in pathological gait patterns from its normal gait parameters $[9,10]$. The development of computer technology and software contributes to data collection, analysis and interpretation of gait data as a tool for studying the function of joints in RA $[9,10]$. Thus, a significant decreased range of the hip, knee, ankle movements (external-internal rotation, abduction-adduction, flexion-extension) under contracture conditions make influence to walking style of RA patients. The walking conditions and pattern of the path violate gait parameters - a decrease in the force and stride interval - articular angular velocities, movement speed and support function in general [10]. In such conditions, along with a pronounced patient's pain reaction, the load on all elements of joints and muscle groups of the lower extremities increases significantly. An increase in mechanical stress, at the background of an inflammatory process, capsular-ligamentous disorders, cartilage degradation, subchondral bone changes and muscle imbalance contribute to the progression of articular and muscle contractures, as well as arthritic phenomena in joints of lower extremities, including the formation of erosions of the articular surfaces [2]. Thus, the importance of mechanical factors in the destructive cascade of processes in $\mathrm{RA}$ is beyond doubt $[3-5,8]$. At the same time, there is insufficient data regarding the muscles functioning in different clinical variants of RA, and routine analysis of muscle activity in clinical practice in this category of patients is usually not performed. The decrease in muscle forces determined by a clinical study is associated with the activity of the inflammatory process, $\mathrm{X}$-ray changes, and the severity of functional disorders [8]. Understanding the values of biomechanical loads on the articular surfaces in the lower extremities joints contracture of RA patients and the participation of muscle forces in this process with the formation of adaptation and compensation mechanisms can contribute to the development of new points of view and approaches to the tactics of therapeutic measures specific to each stage of the disease.

The aim of our study was to analyze the behavior of the musculoskeletal system of a patient with RA in straight walking by calculating the forces acting to the joints of the lower extremities and the main muscle groups of the lower extremities using a simulated musculoskeletal AnyBody model.

\section{Materials and Methods}

The initial data for creating a simulation model were obtained from the examination of patient $\mathrm{K}$. with a diagnosis of rheumatoid arthritis, stage 2 phase 3 , with a predominant lesion of the hip and knee and severe pain in the left hip. The patient's weight is $50 \mathrm{~kg}$, height is $150 \mathrm{~cm}$. In clinical examination, the movements in both hips are significantly limited, acute painful. The flexionadduction contracture in both hips is determined; the relative shortening of the right lower extremity is up to $1 \mathrm{~cm}$. The range of motion in the hips according to the neutral ( 0 to zero) passing method: extension/ flexion - right $0 / 0 / 90^{\circ}$, left $0 / 0 / 70^{\circ}$, abduction/adduction - rocking, external/internal rotation - rocking. The contours of the knee joints are changed, there is a deflection and deformation of both knees, palpation of both knees is painful, flexion-extension contracture is observed in both knees. Active and passive movements are markedly limited. The range of motion in the knee according to the neutral (0 to zero) passing method: extension/flexion - right $0 / 20 / 100^{\circ}$, left $0 / 20 / 100^{\circ}$. The contours of the ankle are changed, deformed. Active and passive movements in the ankle are preserved. In straight walking, the patient assumed a typical body position characteristic of severe forms of RA with combined contractures in the joints of the lower extremities, which determine the typical posture in walking.

At the next stage, the motion capture in the walking was carried out using a video system of 6 cameras and a dynamometric platform. In combination with built-in specialized software modules, the used optical motion capture system (Qualisys Motion Capture System, Sweden) allows high-precision measurement of the position and movements of the fast-moving object or their elements with subsequent processing and analysis of the obtained data. For this, reflective markers were placed on the body of the investigated object, in the projection of the main anatomical landmarks. In straight walking with tread on the dynamometric platform, the trajectories of movement of each marker recorded be the video system and additionally three peak forces: longitudinal (Fx), transverse (Fy), vertical (Fz) (Fig. 1).

The resulting data package in C3D format was exported to the AnyBody Modeling System 6.0 (AnyBody Technology, Danemark) software, which is a system of musculoskeletal modeling for biomechanical simulations based on inverse dynamics, which allows analyzing muscle and joint reactions in the human musculoskeletal system [11]. A musculoskeletal simulation model of the RA patient was created by AnyBody software (Fig. 2), and the calculation of joint and muscle forces was performed [12].

At the final stage, a comparative analysis of the patient's data with the standard model's data of the musculoskeletal system (StandingModel from the AnyBody 

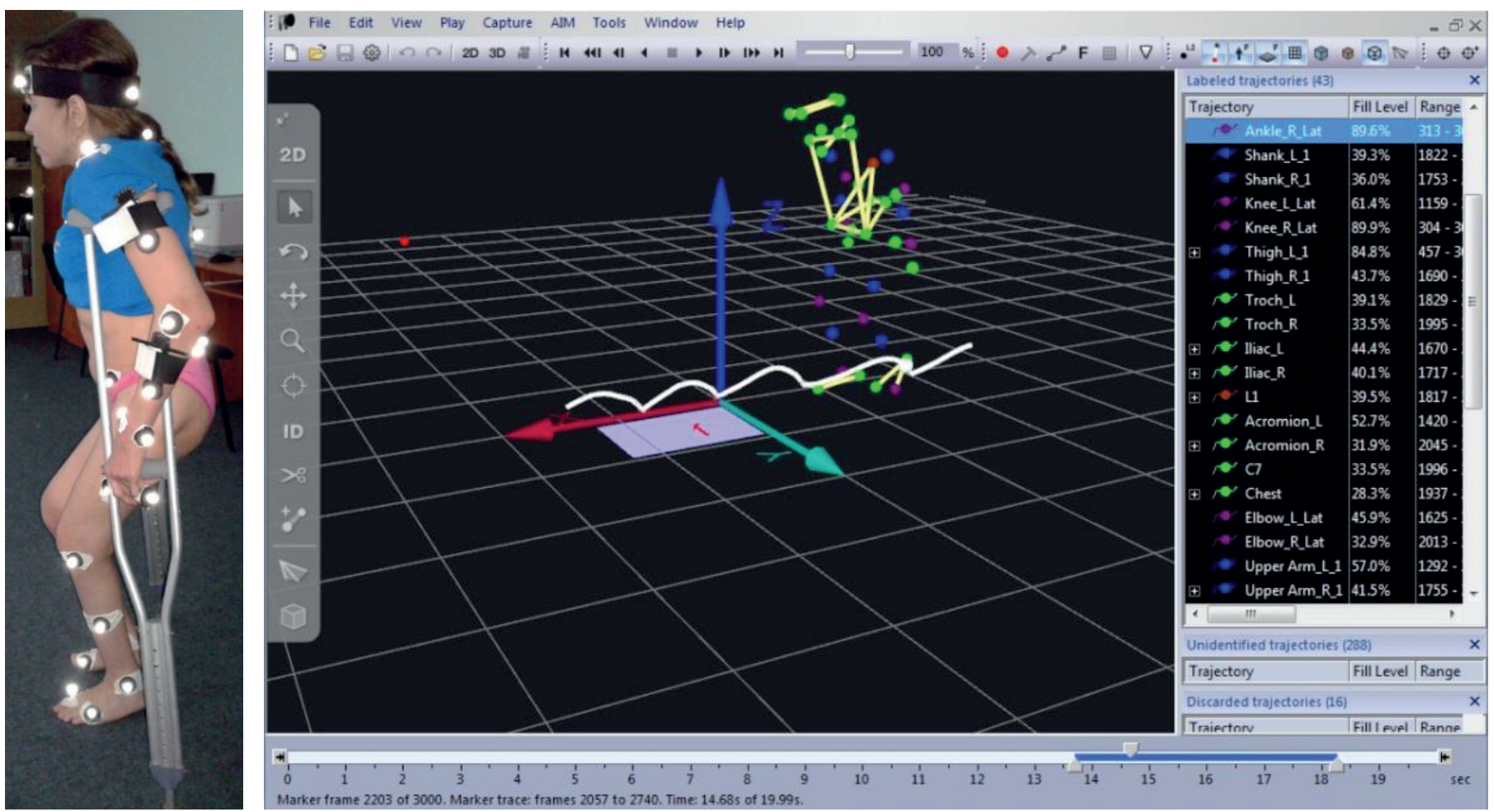

Fig. 1. Registration of the trajectory of markers movement and three peaks of GRF in the window of the software (Qualisys Motion Capture System, Sweden)

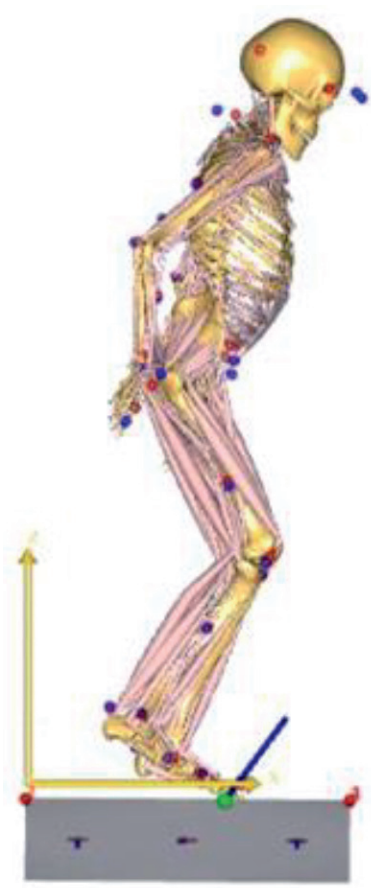

Fig. 2. Musculoskeletal simulation model of the RA patient
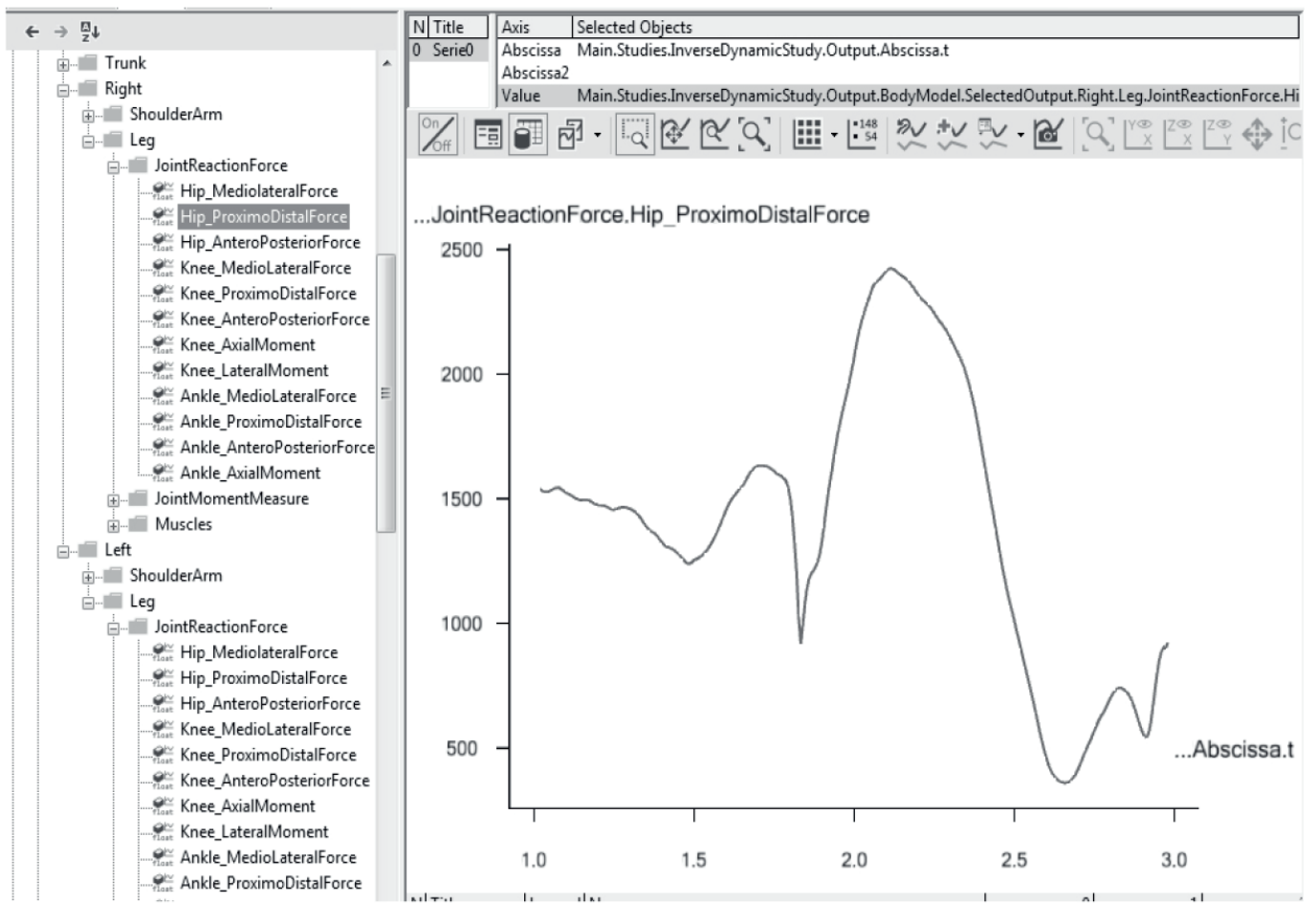

Fig. 3. Joint reaction forces of the hip (vertical component, Z-axis)
Repository AMMR Version 1.6.2 package) was carried out, taken as a conditional norm averaged for both lower extremities. In the context of this work, the joint reaction forces of the hip, knee and ankle were investigat- ed along the $\mathrm{X}$ (longitudinal component), $\mathrm{Y}$ (transverse component), and Z (vertical component) axes (Fig. 3), as well as the muscle forces of the main muscle groups of the lower extremities (Fig. 4). 

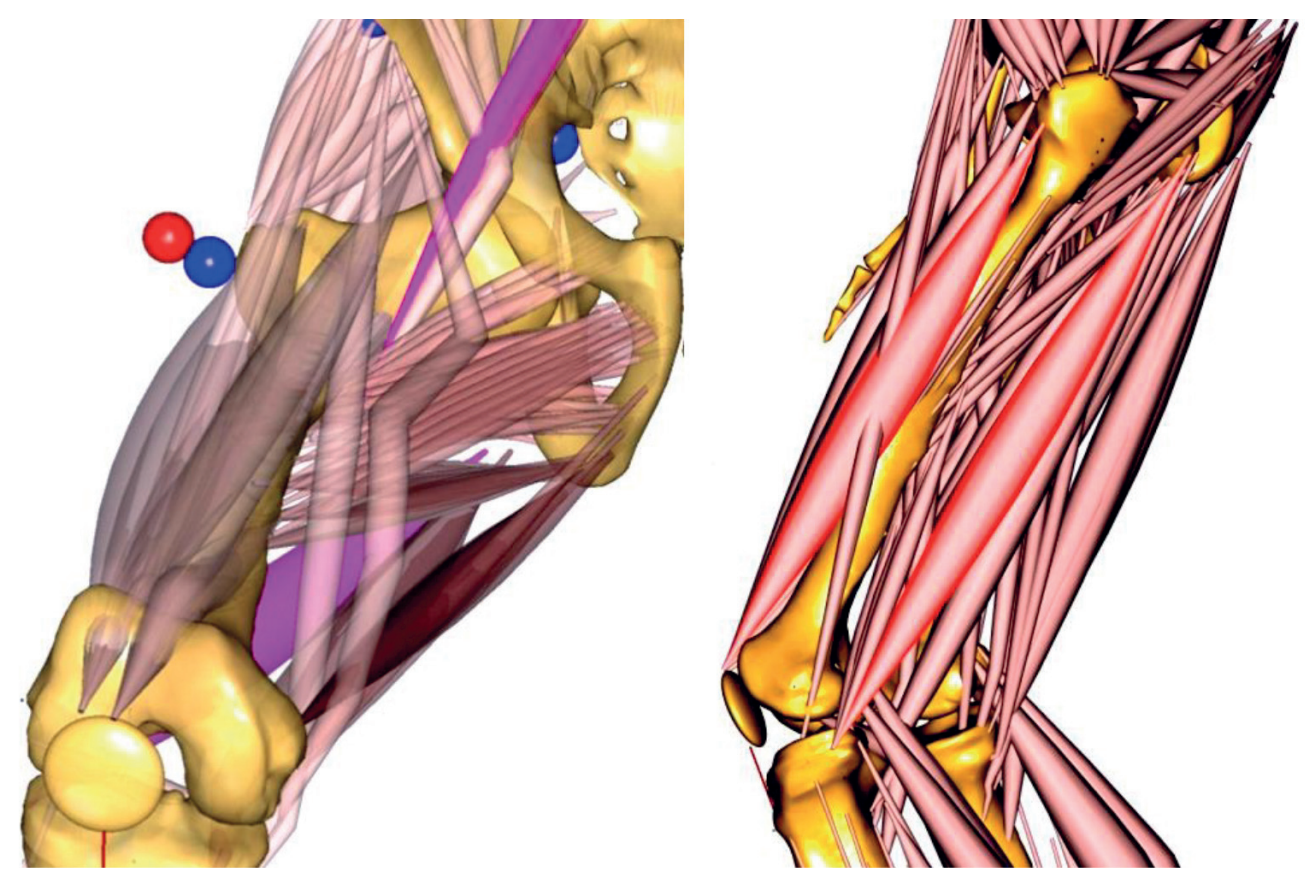

Fig. 4. Muscles of the lower extremities in the AnyBody model

\section{Results and Discussion}

According to the obtained GRF data of the patient, changes in the force and time parameters of the vertical component were revealed. If normally the vertical component of the GRF has two peaks (heel strike force, toeoff force) and a trough between them (mid-stance), then the typical changes in the vertical component of the RA patient were a distortion of the graph curve of GRF's vertical component - the heel strike, and toe-off forces decreasing by $7 \%$ on the right, smoothness of the mid-stance component on both sides and an increasing the single stance time parameters on the left extremity (by $8 \%$ ). Due to the limitation of movements in joints because of pain, the graphs of the vertical component of the GRF acquired a wided form with increasing distance between peaks (more on the left) (Fig. 5). Decreasing of walking speed, heel strike force and toe-off force on the right, increasing of the mid-stance force, show an attempt to unload the right extremity. In general, the gait is static and asymmetric, sparing, due to the fact that the lower extremities loading and push-off from the ground are accompanied by painful sensations.

The values of the muscle forces of the main muscle groups of the lower extremities are presented in Table 1.

As a result of walking modeling in the RA patient with contracture of lower extremities joints, the force is increasing in almost all portions of $\mathrm{m}$. gluteus (maximus, medius, minimus). It was noted in the range from $12 \%$ (GluteusMinimusMid) to 328\% (GluteusMaximusInferior). Only the anterior portions of $\mathrm{m}$. gluteus minimus and $\mathrm{m}$. gluteus medius show decreasing in the force by
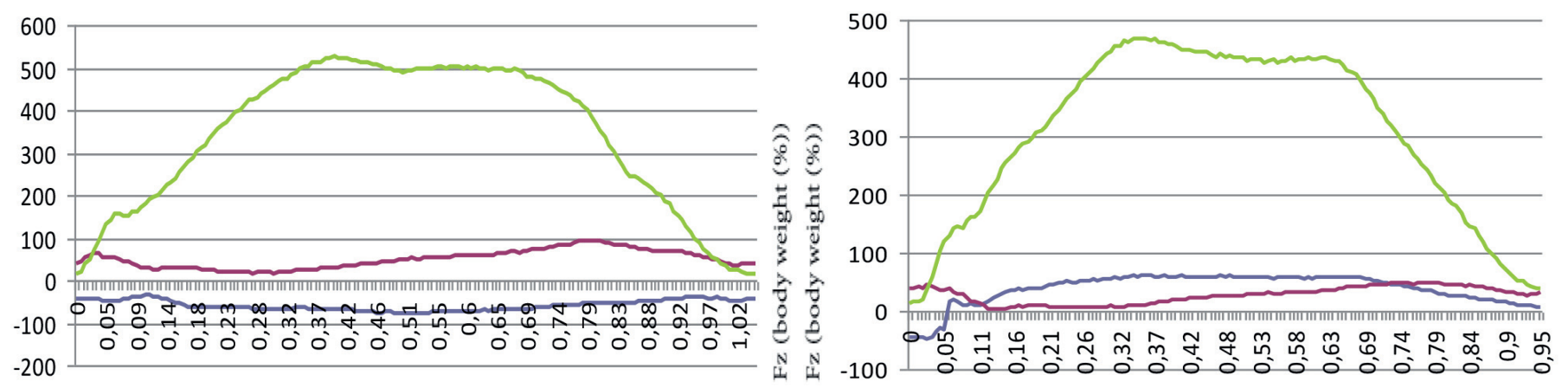

Moment of time $\quad-\mathrm{Fx}-_{\mathrm{Fy}}-_{\mathrm{Fz}}$ Moment of time

A

Fig. 5. Vertical GRF Fz of the left (A) and right (B) lower extremities 
Muscle force parameters of the main muscle groups of the lower extremities

\begin{tabular}{|c|c|c|c|c|c|}
\hline Muscle & Normal & Patient D & Difference (\%) & Patient $S$ & Difference (\%) \\
\hline GluteusMinimusAnterior & 128.41 & 95.49 & -25.63 & 89.24 & -30.50 \\
\hline GluteusMinimusMid & 80.99 & 90.98 & 12.34 & 109.03 & 34.63 \\
\hline GluteusMinimusPosterior & 57.51 & 89.10 & 54.94 & 112.53 & 95.69 \\
\hline GluteusMediusAnterior & 50.18 & 30.21 & -39.80 & 19.97 & -60.20 \\
\hline GluteusMediusPosterior & 87.27 & 180.61 & 106.97 & 228.07 & 161.35 \\
\hline GluteusMaximusSuperior & 11.54 & 45.53 & 294.71 & 26.76 & 131.99 \\
\hline GluteusMaximusInferior & 8.89 & 24.02 & 170.19 & 38.09 & 328.46 \\
\hline GastrocnemiusLateralis & 314.63 & 248.19 & -21.12 & 191.49 & -39.14 \\
\hline GastrocnemiusMedialis & 820.56 & 418.16 & -49.04 & 582.81 & -28.97 \\
\hline SoleusMedialis & 411.27 & 233.06 & -43.33 & 307.61 & -25.20 \\
\hline SoleusLateralis & 353.84 & 376.93 & 6.53 & 205.76 & -41.85 \\
\hline Plantaris & 8.31 & 8.48 & 2.05 & 4.81 & -42.12 \\
\hline Poplitues & 3.06 & 0.88 & -71.19 & 1.74 & -43.04 \\
\hline FlexorDigitorumLongus & 1.64 & 16.10 & 884.71 & 0.00 & -100.00 \\
\hline FlexorHallucisLongus & 25.22 & 138.68 & 449.99 & 0.00 & -100.00 \\
\hline TibialisPosteriorLateralis & 13,61 & 67.70 & 397.43 & 0.00 & -100.00 \\
\hline TibialisPosteriorMedialis & 13.69 & 70.88 & 417.75 & 0.00 & -100.00 \\
\hline TibialisAnterior & 79.77 & 100.28 & 25.71 & 48.01 & -39.81 \\
\hline BicepsFemorisCaputLongum & 259.34 & 443.89 & 71.16 & 593.29 & 128.77 \\
\hline BicepsFemorisCaputBreve & 10.05 & 19.75 & 96.62 & 20.94 & 108.46 \\
\hline Semitendinosus & 168.01 & 221.97 & 32.12 & 196.95 & 17.23 \\
\hline Semimembranosus & 193.04 & 225.70 & 16.92 & 251.70 & 30.39 \\
\hline RectusFemoris & 271.05 & 79.16 & -70.79 & 85.20 & -68.57 \\
\hline VastusLateralisInferior & 3.01 & 1.48 & -50.83 & 3.26 & 8.31 \\
\hline VastusLateralisSuperior & 201.18 & 102.68 & -48.96 & 228.02 & 13.34 \\
\hline VastusMedialisInferior & 13.57 & 6.35 & -53.19 & 14.01 & 3.28 \\
\hline VastusMedialisMid & 50.57 & 24.64 & -51.27 & 54.35 & 7.49 \\
\hline VastusMedialisSuperior & 12.09 & 6.10 & -49.52 & 13.52 & 11.87 \\
\hline VastusIntermedius & 20.25 & 10.32 & -49.02 & 22.93 & 13.26 \\
\hline
\end{tabular}

26-31\% (GluteusMinimusAnterior) and 40-60\% (GluteusMediusAnterior), respectively. Thus, there was the force increasing for GluteusMinimusMid - by 35-91\%, GluteusMinimusPosterior - by 55-96\% (2 times at the more affected side), GluteusMediusPosterior - by 107-161\% (2-2.5 times), GluteusMaximusSuperior - 2-4 times, and GluteusMaximusInferior - 2.5-4 times. At the same time, the force decreasing of the anterior bundles of m. gluteus minimus (by 26-31\%) and m. gluteus medius (by 40-60\%) demonstrate a lack of function associated with internal rotation of the femur.

This is associated with decreasing in hips range of motion in the sagittal plane due to contracture of the joint capsule itself and $\mathrm{m}$. iliopsoas, accompanied by anterior pelvic tilt and hyperlordosis of the lumbar spine. To compensate for movements in the sagittal plane, a 
group of femoral abductors (Gluteus Medius, Gluteus Minimus) are involved in the work. By the reason, amplitude of movements in the frontal plane increases. Thus, the patient's movement in hips flexion contracture and limitation of active extension in RA occurs because of amplitude of compensatory movements in the frontal plane increasing.

Muscle force increasing was also noted in the BicepsFemorisCaputLongum - by $71-129 \%$, BicepsFemorisCaputBreve - by 97-108\%, Semitendinosus by $17-32 \%$, Semimembranosus - by $17-30 \%$. Muscle force decreasing took place in the Gastrocnemius Lateralis - by 21-39\%, Gastrocnemius Medialis - by 29-49\%, Soleus Medialis - by $25-43 \%$, Poplitues - by $43-71 \%$, and Rectus Femoris - by $69-71 \%$. The weakness of the twojoint muscles with a decrease in their involvement occur due to the convergence of attachment zones at the background of a fixed contracture. Flexion position of the knees causes a decrease in the strength of the posterior muscle group of legs. At the same time, there is a compensatory increasing of the BicepsFemoris muscle force, which provides counteraction to the pelvis's anterior tilt.

At the more affected side (left), the FlexorDigitorumLongus, FlexorHallucisLongus, TibialisPosteriorLateralis, TibialisPosteriorMedialis, and TibialisAnterior demonstrate zero MF values in walking, corresponding to pronounced ankle's contracture when these muscles are not involved in the process. At the less affected side (right), these muscle groups have 5-10 times increased values of MF, apparently necessary to ensure compensatory stabilization of the left ankle in the double support phase of the gait. A MF decreasing of the foot's flexor muscles and functional shortening of the lower extremity leads to a compensatory sharp increasing in the load on the Flexor digitorum longus, Flexor hallucis longus and Tibialis posterior muscles.

Asymmetric force values of other muscle groups of the lower extremities with their unilateral increasing and simultaneous decreasing of the contralateral extremity values can be regarded as a compensatory mechanism for the muscle activity distribution aimed at stabilizing the joints at the more affected side and muscle unloading at the less affected extremity.

The patterns of MF distribution in RA patients correspond to changes in the joint reaction forces (JRF) acting in the hip, knee and ankle along the $\mathrm{X}, \mathrm{Y}$ and $\mathrm{Z}$ axes. $\mathrm{JRF}$ and the moments of forces are presented in Table 2.

As a result of modeling of the RA patient walking, there is all JRF vectors increasing acting in both hips: transverse (Y-axis) - by 143-181\%, vertical (Z-axis) by $10-52 \%$, longitudinal (X-axis) - by $112-170 \%$. Biomechanical overload of the articular surfaces of the hip joints can serve as a factor of the degenerative processes development or further progression of arthritis and joint stiffness.

In the knees, JRF acting in the longitudinal direction (X-axis), at the more affected side (left), are significantly increased - by $82 \%$; on the less affected side close to normal parameters ( $2 \%$ difference). Vertical JRF (Z-axis) are decreased by 10-36\% at both sides. Lateral JRF (Y-axis) are increased by 18\% at the more affected side (left) and decreased by $14 \%$ at the contralateral side compared to normal parameters. This difference

JRF of the bip and knee (D and S) of the RA patient

\begin{tabular}{|l|c|c|c|c|c|}
\hline \multicolumn{1}{|c|}{ Joint } & Normal & $\begin{array}{c}\text { Lower } \\
\text { extremity D }\end{array}$ & $\begin{array}{c}\text { Difference } \\
\text { (\%) }\end{array}$ & $\begin{array}{c}\text { Lower } \\
\text { extremity S }\end{array}$ & $\begin{array}{c}\text { Difference } \\
\text { (\%) }\end{array}$ \\
\hline Hip_MediolateralForce $(\mathrm{Y})$ & 674.81 & 1639.23 & 142.92 & 1895.59 & 180.91 \\
\hline Hip_ProximoDistalForce (Z) & 2196.30 & 2418.05 & 10.10 & 3337.46 & 51.96 \\
\hline Hip_AnteroPosteriorForce (X) & 209.12 & 443.04 & 111.86 & 565.19 & 170.27 \\
\hline Knee_MedioLateralForce (Y) & 479.33 & 410.08 & -14.45 & 564.50 & 17.77 \\
\hline Knee_ProximoDistalForce (Z) & 2512.32 & 1613.18 & -35.79 & 2265.62 & -9.82 \\
\hline Knee_AnteroPosteriorForce (X) & 804.20 & 820.35 & 2.01 & 1464.19 & 82.07 \\
\hline Knee_AxialMoment & 6.40 & 22.46 & 250.94 & 29.45 & 360.16 \\
\hline Knee_LateralMoment & 48.61 & 25.37 & -47.80 & 49.05 & 0.92 \\
\hline Ankle_MedioLateralForce (Y) & 901.07 & 806.69 & -10.47 & 666.60 & -26.02 \\
\hline Ankle_ProximoDistalForce (Z) & 3864.81 & 3310.55 & -14.34 & 2689.84 & -30.40 \\
\hline Ankle_AnteroPosteriorForce (X) & 619.29 & 341.01 & -44.93 & 758.23 & 22.44 \\
\hline Ankle_AxialMoment & 9.79 & 8.20 & -16.20 & 5.17 & -47.16 \\
\hline
\end{tabular}


can be explained by the compensatory mechanism of load redistribution between the extremity more and less involved in the pathological process [13]. The decrease in the magnitude of vertical JRF can explain the increasing stiffness of the posterior parts of the knee's capsule as a result of a long-term inflammatory process, followed by its fibrosis and formation of contracture. Ultimately, an additional extra-articular point of rotation forms. At the same time, due to the compensatory increasing in the MF magnitude of the posterior femoral muscles involved in maintaining the knees flexion position in walking, the articular surfaces are unloaded by decreasing in the vertical JRF (Z-axis) magnitude.

In the ankles, there is a decrease in lateral JRF (Y-axis) - by 10-26\% and vertical JRF (Z-axis) - by 14$30 \%$, while the longitudinal JRF (X-axis) increased by $22 \%$ at the more affected side (left) and decreased by $45 \%$ at the less affected side. This can also explain the compensatory load redistribution between the extremities.

In addition, axial rotational moment magnitude increasing in both knees by 3-4 times compared with the normal parameters, as well as a 16-47\% decreasing in the ankle axial moment, should be noted. According to the study, deviations of the force moments from the reference values can explain the phenomena of the knee and ankle instability in RA patients.

Thus, the load distribution changes, caused by joints contractures and pain syndrome, have a certain positional adaptation of the pelvis and lower extremities. This is due to activation of the body compensatory mechanisms associated with the muscle activity transfer from one group to others, which ultimately results in functional antalgic intraarticular relationships. The most common lower extremity joint conditions in RA patients are flexion-adduction contracture in the hip and flexion-valgus position of the knee. Joint capsule relaxation and intra-articular pressure decreasing can reduce the pain response. However, the intra-articular relationships achieved in this case significantly impair the biomechanical functions of support and movement of the lower extremities, which are compensated by additional muscle tension. Unilateral flexion-adduction position of the lower extremity leads to its functional shortening, femoral internal rotation, and a decrease in the area of ground contact. Bilateral functional shortening of the lower extremities is compensated by pelvic anterior rotation with formation of permanent $\mathrm{m}$. iliopsoas contracture and lumbar hyperlordosis. Maintaining the obtained vertical body position is accompanied by postural muscle imbalance, which reduces the MF of m. quadriceps femoris. Adduction and flexion of the thigh leads to reflexive activation of the antagonist muscles (m. gluteus maximus and $\mathrm{m}$. gluteus medius) to stabilize the extremity. The convergence of attachment points of the m. gluteus maximus and anterior portion of the m. gluteus medius leads to their weakness. For compensation of decrease in the area of ground contact, the muscles turning knees in valgus position are activated (m. biceps femoris and $\mathrm{m}$. tensor fasciae latae with an active role of m. gluteus maximus). Fixed position of the knee leads to the lateral and medial head of the $\mathrm{m}$. gastrocnemius and $\mathrm{m}$. soleus weakness. An attempt to compensate functional shortening of the extremity leads to fixation of the ankle in the plantar flexion position with formation of its contracture. The etiopathogenetic factor of inflammation plays a secondary role in this case.

The MF redistribution is compensatory and aimed to keep the RA patient in upright position and optimize the biomechanics of walking due to the less painful movements.

\section{Conclusions}

1. According to the study of the RA patient walking with flexion-adduction lower extremities joints contractures, a compensatory redistribution of muscle forces was revealed, aimed at keeping the body in an upright position and optimizing the biomechanics of walking by increasing the amplitude of compensatory movements in the frontal plane.

2. The presence of the hip and knee contractures is accompanied by postural muscle imbalance with a decrease in the muscle forces of the lower extremities, except for the m. gluteus, m. biceps femoris, m. semitendinosus and $\mathrm{m}$. semimembranosus, demonstrating a compensatory increase in their force characteristics.

3. A significant increase in biomechanical loads on the articular surfaces in RA patients with contracture of the lower extremities joints, as well as the contribution of muscle forces to this process, can be both a factor supporting the inflammatory response of the joints and a factor in the development of degenerative processes or further progression of arthrosis phenomena in the hips and knees.

Conflict of interest. The authors declare no conflict of interest. This publication has not been, is not, and will not be the subject of commercial interest in any form.

\section{References}

1. Sigidin YA, Lukina GV. Rheumatoid arthritis; M: ANKO; 2001. $328 \mathrm{p}$.

2. Kovalenko VN. Rheumatoid arthritis: etiopathogenesis, clinical picture, diagnosis, treatment. Liki Ukrainy. 2005;3(92):18-20. 3. Sun HB. Mechanical loading, cartilage degradation, and arthritis. Ann NY Acad Sci. 2010;1211:37-50.http://dx.doi. org/10.1111/j.1749-6632.2010.05808.x.

4. Jessome MA, Tomizza MA, Beattie KA., Bensen WG, Bobba RS, Cividino A, et al. Anatomical Patterns Suggest the Involvement of Biomechanical Stress in the Pathogenesis of Erosions in 
Rheumatoid Arthritis. ACR/ARHP 2016 Annual Meeting. American College of Rheumatology. 2016; Nov 11-16; Washington, US. 5. Guilak F. Biomechanical factors in osteoarthritis. Best Practice \& Research. Clinical Rheumatology. 2011;25(6):815-23. http://dx.doi.org/10.1016/j.berh.2011.11.013.

6. Häkkinen A, Kautiainen H, Hannonen P, Ylinen J, Mäkinen $\mathrm{H}$, Sokka T. Muscle strength, pain and disease activity explain individual subdimensions of the Health Assessment Questionnaire disability index, especially in women with rheumatoid arthritis. Ann Rheum Dis. 2006;65:30-4. http://dx.doi.org/10.1136/ ard.2004.034769.

7. Stucki G, Schönbächler J, Brühlman P, Mariacher S, Stoll T, Mechel BA. Does a muscle strength index provide complementary information to traditional disease activity variables in patients with rheumatoid arthritis? J Rheumatol. 1994;21:2200-5.

8. Uutela TI, Kautiainen HJ, Häkkinen AH Decreasing muscle performance associated with increasing disease activity in patients with rheumatoid arthritis. PLoS ONE. 2018;13(4). https:// doi.org/10.1371/journal.pone.0194917.
9. Baan H, Dubbeldam R, Nene AV, Laar M. Gait Analysis of the Lower Extremity in Patients with Rheumatoid Arthritis: A Systematic Review. Seminars in Arthritis and Rheumatism. 2012 June;6(41):768-88.

10. Isacson J, Broström LA. Gait in rheumatoid arthritis: an electrogoniometric investigation. J Biomech. 1988;21(6):451-7. http://dx.doi.org/10.1016/0021-9290(88)90237-0.

11. Rasmussen J, Zee M, Damsgaard M, Christensen ST, Andersen MS. Musculoskeletal simulation of orthopedic surgical procedures. Poster presentation at the Workshop Proceedings of Computational Biomechanics for Medicine. MICCAI 2006, Copenhagen, Denmark, 2006.

12. Damsgaar M, Rasmussen J, Christensen ST, Surma E, Zee M. Analysis of musculoskeletal systems in the AnyBody Modeling System. Simulation Modelling Practice and Theory. 2006;14(8):110011. https://doi.org/10.1016/j.simpat.2006.09.001.

13. Konrath JM, Karatsidis A, Schepers HM, Bellusci G, Zee M, Andersen M.S. Estimation of the Knee Adduction Moment and Joint Contact Force during Daily Living Activities Using Inertial Motion Capture. Sensors. 2019;19(7):1681. https://doi.org/10.3390/s19071681/.

\section{Біомеханічний аналіз суглобових і м'язових сил нижніх кінцівок в акті ходьби при ревматоїдному артриті}

Герасименко С.I. ${ }^{1}$, Лазарев I.A. ${ }^{1}$, Герасименко А.С. ${ }^{1}$, Бабко А.M. ${ }^{1}$, Полулях M.B. ${ }^{1}$, Литвиненко Ю.В. ${ }^{2}$, Жирнов О.В. ${ }^{2}$, Мальований С.Д. ${ }^{3}$, Максимішин О.М. ${ }^{1}$

'ДУ "Інститут травматології та ортопедї НАМН України", м. Київ

${ }^{2}$ Національний університет фізичного виховання і спорту Украйни, м. Київ

${ }^{3}$ Начіональний технічний університет України "Київський політехнічний інститут імені Ігоря Сікорського", м. Київ

Резюме. Ревматойднии артрит (РА) - імуномодульоване хронічне запальне захворювання, яке супроводжується розростанням запаленої синовіальної оболонки та руйнуванням суглобового хряща, що призводить до утворення контрактури суглобів нижніх кінцівок та інвалідності. Розуміння значень біомеханічних навантажень на суглобові поверхні при контрактурі суглобів нижніх кінщівок у хворих на РА та участі м'язових сил у щьому процесі з формуванням механізмів адаптащії та компенсації може сприяти розробиі нових поглядів та підходів до лікування, тактики терапевтичних заходів, спещифічних для кожної стадії захворювання. Мета дослідження. Аналіз поведінки скелетно-м'язової системи пацієнта з РА при ходьбі шляхом розрахунку сил, що діють в основних м'язових групах і суглобах нижніх кінцівок. Матеріали і методи. Вихідні дані отримані на підставі даних дослідження пащієнтки К. $з$ діагнозом: ревматоїдний артрит, 2 ст., 3 фаза з переважним ураженням кульшових i колінних суглобів, вираженим больовим синдромом у лівому кульшовому суглобі. Відеосистема з 6 камер, світловідбивних маркерів і динамометричної платформи використовувалася для відеореєстрації ходьби. Створено імітащійну скелетно-м'язову модель ходи пащієнта з РА в програмному забезпеченні AnyBody Modeling System 6.0 (Данія). Розраховано суалобові (JRF) та м'язові сили (MF). Результати. Для колпенсаиї структурних порушень у суглобах хворих на РА змінюється звичайний режим навантаження кінцівок. Піки вертикальної складової опорних реакцій знижені порівняно з показниками нормальної популячії, хода статична та асиметрична, щадна. MF зростають в m. gluteus (maximus, medius, minimus), збільшується амплітуда рухів у фронтальній площині. JRF обох стегон збільшуються у всіх площинах. Висновки. Ходъба хворих на РА з обмеженням активного розгинання у кульшових та колінних суглобах відбувається за рахунок збільшення апплітуди компенсаторних рухів у фронтальній площині. Постуральний дисбаланс м'язів зменшує МF нижніх кінщівок, за винятком сідничнх, двоголових м'язів стегна, напівсухожильного та напівперетинчастого м'язів, MF яких збільшуються. Перерозподіл MF є компенсаторним і спря- 
мований на утримання пацієнта з РА у вертикальному положенні та оптимізацію біомеханіки ходьби за рахунок менш болючих рухів. Біомеханічне перевантаження суалобових поверхонь кульшових $і$ колінних суглобів може служити чинником підтрикки запальної реакції, розвитку дегенеративних процесів або подальшого прогресування артрозу та скутості суглобів нижніх кінцівок у цієї категорії хворих.

Ключові слова: ревматоїднии артрит; контрактури суглобів; скелетном'язова модель AnуBоdy; суглобові сили; м'язові сили.

\section{Биомеханический анализ суставных и мышечных сил нижних конечностей в акте ходьбы при ревматоидном артрите}

Герасименко С.И. ${ }^{1}$, Лазарев И.А. ${ }^{1}$, Герасименко А.С. ${ }^{1}$, Бабко А.Н. ${ }^{1}$, Полулях М.В. ${ }^{1}$, Литвиненко Ю.В. ${ }^{2}$, Жирнов А.В. ${ }^{2}$, Мальованый С.Д. ${ }^{3}$, Максимишин О.М. ${ }^{1}$

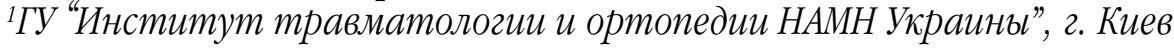

${ }^{2}$ Начиональный университет физического воспитания и спорта Украины, г. Киев

${ }^{3}$ Начиональный технический университет Украины "Киевский политехнический институт имени Игоря Сикорского", г. Киев

Резюме. Ревматоидный артрит (РА) - иммуномодулированное хроническое воспалительное заболевание, сопровождающееся разрастанием воспаленной синовиальной оболочки и разрушением суставного хряща, что приводит к образованию контрактуры суставов нижних конечностей и инвалидности. Понимание значений биомеханических нагрузок на суставные поверхности при контрактуре суставов нижних конечностей у больных РА и участия мышечных сил в этом процессе с формированием механизмов адаптации и компенсации может способствовать разработке новых взглядов и подходов к лечению, тактике терапевтических мероприятий, спещифичных для каждой стадии заболевания. Цель исследования. Анализ поведения скелетно-мышечной системы пащиента с РА при ходьбе путем расчета сил, действующих в основных мышечных группах и суставах нижних конечностей. Материалы и методы. Исходные данные получены на основании данных исследования пащиентки К. с диагнозом: ревматоидный артрит, $2 \mathrm{~cm}$., 3 фаза с преимущественным поражением тазобедренных и коленных суставов, выраженным болевым синдромом в левом тазобедренном суставе. Видеосистема из б камер, светоотражающих маркеров и динамометрической платформы использовалась для видеорегистрации ходьбы. Создана имитационная скелетно-мышечная модель походки пащиента с РА в програмином обеспечении AnyBody Modeling System 6.0 (Дания). Рассчитаны суставные (JRF) и мышечные силы (MF). Результаты. Для компенсации структурных нарушений в суставах пациентов с РА изменяется обычный режим нагрузки нижних конечностей. Пики вертикальной составляющей опорных реакиий снижены по сравнению с показателями нормальной популящии, походка статическая и асимметричная, щадящая. MF возрастают в m. gluteus (maximus, mеdius, minimиs), увеличивается алплитуда движений во фронтальной плоскости. $J R F$ обоих бедер увеличивается во всех плоскостах. Выводы. Ходьба больных РА с ограничением активного разгибания в тазобедренных и коленных суставах происходит за счет увеличения алплитуды компенсаторных движений во фронтальной плоскости. Постуральный дисбаланс мыши уменьшает МF нижних конечностей, за исключением седалищных, двуглавых мыши бедра, полусухожильной и полуперепончатой мыши, MF которых увеличиваются. Перераспределение MF является компенсаторным и направлено на удержание пащиента с РА в вертикальном положении и оптимизацию биомеханики ходьбы за счет менее болезненных движении. Биомеханическая перегрузка суставных поверхностей тазобедренных и коленных суставов может служить фактором поддержания воспалительной реакиии, развития дегенеративных процессов или дальнейшего прогрессирования артроза и скованности суставов нижних конечностей у данной категории больных.

Ключевые слова: ревматоидныи артрит; контрактуры суставов; скелетномышечная модель AnуBоду; суставные силы; мымечные силы. 